\title{
Plan the Business of a Vessel of a Tramp Shipping Company
}

\author{
Alexandros M. Goulielmos ${ }^{1,2}$ \\ ${ }^{1}$ Department of Maritime Studies, Faculty of Maritime and Industrial Studies, University of Piraeus, \\ Piraeus, Greece \\ ${ }^{2}$ Shipping Department, Business College of Athens, Athens, Greece \\ Email: ag@unipi.gram.goulielmos@hotmail.com, agoulielmos@bca.edu.gr
}

How to cite this paper: Goulielmos, A.M (2019) Plan the Business of a Vessel of a Tramp Shipping Company. Modern Economy, 10, 1633-1653.

https://doi.org/10.4236/me.2019.106107

Received: April 19, 2019

Accepted: June 27, 2019

Published: June 30, 2019

Copyright (C) 2019 by author(s) and Scientific Research Publishing Inc. This work is licensed under the Creative Commons Attribution International License (CC BY 4.0).

http://creativecommons.org/licenses/by/4.0/

\begin{abstract}
We described the procedure, and the importance, of the budget or plan of expenses (cost) of a vessel in a tramp shipping company, and also we addressed the difficulty to plan receipts (revenue). We analyzed the structure of a shipping company in departments and their particular role in spending and collecting money. Leaving, for a while, aside reality, we analyzed the true objective of a vessel, which is to minimize cost. Vessel's half-square isoquant is presented as well her economies of scale. In fact, we revealed seven objectives for a vessel, the first being the rather meaningless in shipping one of maximizing normal profits. For the first time, we proposed planning for a maritime depression, described here as a common feature in shipping (one every 12 years). We have presented Management by Objectives and optimal management by objectives as future candidates for shipping companies. The main contribution of this paper is our attempt to modify the present: management by distance by future management by looking at...
\end{abstract}

\section{Keywords}

Shipping, Budget, Depression Plan, Minimize Vessel's Cost, Revenue, Planning, Management by Objectives (MbO), Optimal MbO, Management by Looking at

\section{Introduction}

A manager has to coordinate and oversee the work activities of others so that to be efficient and effective [1]. Effective means: do the "right things" (to achieve company's goals), something easy if... not accompanied by efficiency. Efficiency means: "do things right" (economically) or the cost of a decision to be lower 
than the income derived from... Is this the well-known Economic Principle ${ }^{1}$ ?

The above two principles of management are applicable also to Captains, the managers of the vesses. Economics, however, says that a firm has to "maximize normal profits" (M1), provided one used the best available technology. Technology to a manager promises a maximum technical result, and economics promises a maximum economic result. Management promises nothing... unless things are done efficiently and effectively... Economics seem to believe in rather automatic economic forces and only requires MC (Marginal cost) to be equal to MR (Marginal revenue). Management believes that the role of manager is to make things happen.

Planning ${ }^{2}$ in a firm is an important management function, together with the other three: organizing, controlling and leading. These four functions metaphorically are the feet of the chair on which top-managers sit. Using all four feet managers remove the danger to fall (fail).

However, we suspect that the reader may be surprised from the fact that a shipping company can plan, doing businesses in a highly volatile and unpredictable environment! From my, almost 15 years, experience from managing 1 insurance company and 2 departments in a large Greek tramp ${ }^{3}$ shipping company, since 1977, I have been taught that the prime management function, in a shipping company, is control... based on Planning. Planning and control are indeed twin sisters, who manage wisely a shipping company as well company's vessel(s).

The vessel is a floating, and moving internationally, factory of producing sea transport services, and if she avoids human error, is the stable value for a shipping company. An efficient and effective shipping company has to focus, no doubt, on vessels. Moreover, a shipping company will be defined as a set of vessels.

The size of shipping companies increased since 1960s from a single vessel, or from few. Shipping always was volatile, but more so since large modern ships appeared in horizon in 1960s. "Bigger ships, bigger troubles", says popular wis$\mathrm{dom}^{4}$. Perhaps one may think that studying vessel, her company is ignored. We felt, however, that the vessel, in all papers we read, is taken for granted, she is... literally and really out of sight, while she should be the core subject of the interest of Managers, Captains and Academia.

The more frequent shipping managers had to manage... by distance, the more Captains undertook the highly responsible role of a local manager. At the

\footnotetext{
${ }^{1}$ A ship e.g. had to pay $\$ 100$ to obtain a missing map (discovered by Port State Control (PSC)). This would entail delaying ship, say 3 hours, if her Captain decides to wait for the map to arrive at present port. This decision costs $\$ 875$ (the running cost of the vessel for 3 hours). So, the decision to depart immediately, and receive the map in next port, (allowed by PSC), is efficient.

${ }^{2}$ To plan means: to set goals, establish strategies for achieving them and develop plans to integrate and coordinate work.

${ }^{3}$ Tramps are the ships that travel from port A to B on demand.

${ }^{4}$ Most non-shipping companies were fortunate in the past to act in a stable environment, like e.g. "Publishing Houses". The current year for them was more or less like last year and so were next years.
} 
same time, the control of the vessel became crucial, as the vessel is producing out of sight of top-management. Captains became the alter ego ${ }^{5}$ of top-managers and their selection, and their (in-house) training, became more essential. From the above is made clear that vessel's Captains have to manage the ship and the crew, efficiently and effectively.

The last 40 years or so, the world became one village (=globalization), and thus no one can do businesses in isolation. The actions of one company affect the others, and the world became one system of smaller systems, as argued by Chaos and Complexity Theory [2]. This structural change means that during peace (business as usual; a boom), top-managers must be prepared, and plan, for war (i.e. for depressions)! Managers should be alert. Planning prepares managers for the next day!

The aim is to show how to plan a budget of a large tramp shipping company, to present nine plans, (and one $10^{\text {th }}$ ), which theory provides and to show which plan is suitable for what. Moreover, to show that in a tramp shipping company, revenue cannot be planned and to indicate why to plan in general. Finally, to show what a vessel has to minimize; and present $\mathrm{MbO}$ and optimal $\mathrm{MbO}$ and the novel management by looking at.

The paper is structured in six parts after literature review: Part I, deals with the yearly planning of vessel's Expenses. Part II, identifies the three main departments/sections of a shipping company, which bring-in money. Part III, turns the emphasis from firm's normal profit maximization to vessel's cost minimization. Part IV, deals with Planning. Part V deals with Management by objectives $(\mathrm{MbO})$ and optimal MbO. Part VI, proposes a way of "managing ships by looking at"... Finally, we conclude.

\section{Literature Review}

Despite their importance, books dealing with management of shipping companies are very few. This is due to the fact that a small number knows this subject well, and from inside. This is further so because managers of shipping companies rarely abandon their well-paid positions to follow a University career, pre-requiring also a doctoral thesis. Moreover, those teaching management of shipping companies in Universities, who are few anyway, rarely abandon their post, to become managers in a shipping company ${ }^{6}$.

Downard [3], wrote about (running) costs of a shipping company. Budget was explained as well the management functions of Planning and Control. He wrote that "if you don't know where you're going, any road will take you" there (p. 1) and "all plans require: objective", time scale, implementation, realism with challenge and personal commitment" (p. 3). He also argued that "having a plan, ${ }^{5}$ The times where owner managed on board his vessel are passed forever! ${ }^{6}$ When I was in London in mid-1970s finishing my doctoral thesis in shipping economics, I wanted to work in a shipping company. A famous Greek shipowner called me in his office in the City of London: he had a son, who had a doctoral thesis (in Chemistry), but he did not want to work in his father's company...

${ }^{7}$ Modern management replaced objective by objectives. 
putting it into action and then continuously monitoring and adjusting it to achieve the objective, often to suit changing needs", is control (p. 94). "In ship management", there are two, both required, goals: "to achieve the plan and to achieve the Budget" [3]. He mentioned also management by objectives (MBO) as "a technique which is very much part of many of the philosophies on which his book was based" [3].

Downard [4], at age of 56, having a long service at sea on tramp ships and bulk carriers, since 1968, held also various positions in shipping companies, wrote about managing ships. He was Managing Director from 1975 to 1979 of the London ship management company of the Fairfield Maxwell Group. On the subject of planning he wrote (p. 10): "once plans and budgets approved at a senior level, they should be adhered as far as possible" and "keeping plans and budgets on target requires the necessary discipline of controls".

Robbins [5] argued that $\mathrm{MbO}$ is a well-known philosophy of management, which assesses an organization and its members by how well they achieve the specific goals. Goals, which the superiors and subordinates, jointly established. $\mathrm{MbO}$ represents the ultimate in a goal-oriented approach to effectiveness.

Erskine [6] mentioned seven significant characteristics of $\mathrm{MbO}$, and the difficulties of its implementation. $\mathrm{MbO}$, among others, pre-needs a credible corporate plan. Romani [7] argued that $\mathrm{MbO}$ works by using: goal specificity, participative decision-making, explicit time periods and performance feedback.

A wealth of empirical knowledge about shipping and vessels' management is provided by Buckley [8] aged 58. His book was first written by Kendall L (in 1973), who passed away in 1999. Buckley wrote (p. xi) that the purpose of his book was to "provide the reader with an accurate description of the length and breadth of maritime industry, and an overview of the business side of the commercial maritime field".

Most shipping management books have a strong empirical content and are less theoretical, if at all. In shipping, we believe, the balanced combination of theory and practice has to be sought after. McConville [9], e.g., tried to express maritime economics as an applied branch of Neoclassical Economics.

Professor Lorange P. [10], wrote about shipping strategies and the innovation for success, who used also to be a shipowner! His book, written ${ }^{8}$ in mid-2008, had as a target the sophisticated shipping industry practitioner (p. xv). He tried to develop the most relevant critical success factors for shipping business in general, and to identify the various key-shipping-strategies, in particular. Certain of his main views are shown in Figure 1.

As shown, five cultures are needed by a top-manager to have a successful shipping firm, according to Lorange [10]: 1) A keen understanding of market (with a good feel for turning ${ }^{9}$ points). 2) Knowledge of: brokerage, trading, and

${ }^{8} \mathrm{He}$ denied the influence that the 5 years of an exceptional shipping boom (2003-2008) had on what he wrote. In fact he sold his company during this very good time. He wrote that the per day spot freight rate for a Cape in June 2008 was \$230,000; while in Nov. 2008 was \$4,000!

${ }^{9}$ How is this achieved? 


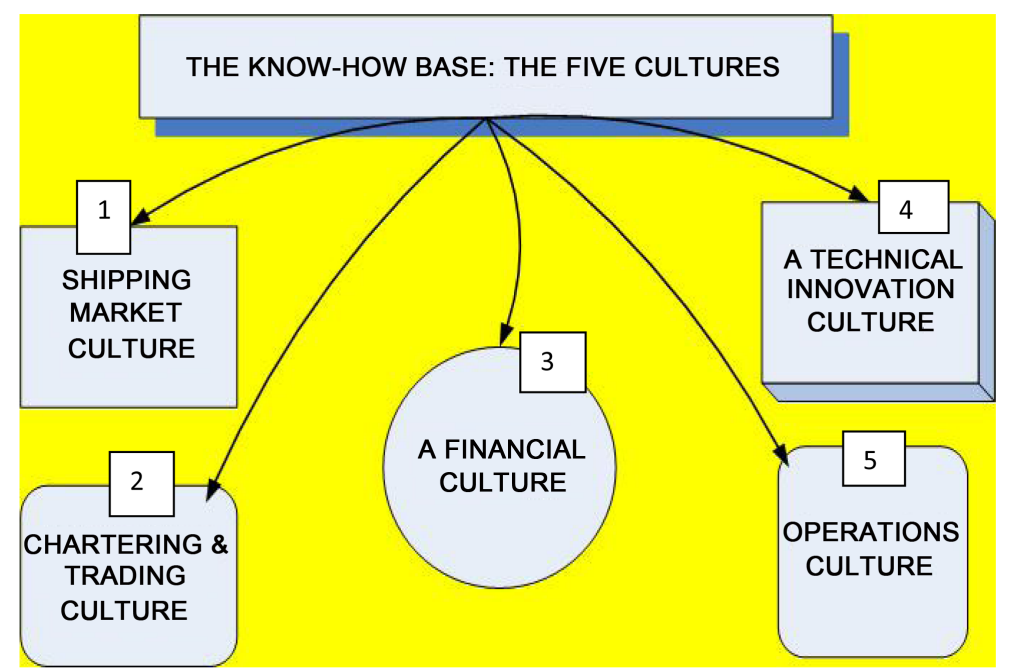

Figure 1. The know-how base. Source: Inspired by Lorange [10].

having expertise to pursue charterer-focused strategies. 3) Ability to manage financial flows and budgets (=currencies, interest rates, new instruments and derivatives -FF market trading etc.) (i.e. the subjects of "Financial Engineering"). 4) Pushing for better solutions, including forecasting. 5) Ability to make something good, or better, by having the necessary know-how for the operation and recruitment of a ship, focusing on delivering the best possible services at the lowest possible cost.

Important is company's customers views about their need for transportation support, given that the configurations of supply chains are constantly changing. To this, technological factors contribute, among other factors. In shipping, permanent pre-occupations are: the new navigational equipment, engines with sophisticated fuel injection, new hull designs, more efficient propulsion, and low-friction. Innovationsin ships come also from legislation (legal obsolescence) (double-hull tankers, since 2010; more environmental-friendly ships).

Lorange [10] did not distinguish between the existing, for us, two different shipping management styles, though he provided a great amount of empirical knowledge about large international shipping companies. In fact, he was critical against family-based shipping companies (1st style) and in favor of stock-exchange-based ones ( $2^{\text {nd }}$ style).

"Management by objectives" (MbO) replaced the method of "traditional goal-setting" [1]. This assumed that the staff below top-management was for executing the goals coming exclusively from the top. The contribution and participation of all others, except top-management, was not necessary. Next the "means-ends chain" introduced, when it was understood that everyone in a company is better to have his/her own goal [11].

$M b O$ is known as management by results $(M b R)$. Drucker popularized MbO, since 1954 [12], but this also applied by companies like: Hewlett-Packard, Zerox, Intel, DuPont and others; it was also adopted by the Japanese. In 2016 emerged the "optimal MbO" (OMbO) [13], giving emphasis to leader's support. He ar- 
gued that MbO fails if top-management did not support it (p. 50). When, he argued, top-management's commitment was high, the average productivity gain was $56 \%$ (vis-à-vis $6 \%$ )!

In shipping, the support to $\mathrm{MbO}$ comes definitely from the Economic Manager and Chief Accountant. In Greek shipping companies have a centralized decision-making (in another context: Duffy [14]; Guiso et al. [15]. He [13] argued that OMbO borrows elements from the "field of restructuring and corporate turnaround".

Summarizing, forecasting is necessary, but how is this achieved? [16] Greek shipowners do not trust forecasting believing it is always wrong... Their decisions come true whatever market does! [17] We agree also that the cost control is a pre-requisite for success. Lorange mentioned only once [10] the utmost crucial role of liquidity for us! Especially if a shipping company undertook expensive new-buildings and next entered into a shipping depression!

\section{Part I: Planning Expenses in a Shipping Company}

Planning in a shipping company is carried-out for next 12 months and at the end of prior year. Planning must be saved in company's computer(s) and be ready the latest by $31^{\text {st }}$ December of the planning year. Large shipping companies have also a budget manual to enable their staff to accomplish budget as accurate as possible.

Planning is required for top-management to see why plans fail! This is quite important to realize the reasons, for which company's planning tools and methods, were ineffective. This is a procedure, call it: "learning by mistake" (LbM). LbM is something we met in shipping companies, but in operations! LbM should not be unlimited, we believe.

Planning may be combined with learning by doing ${ }^{10}$ (LbD). LbD we found in shipping companies, which were able to learn, adapt and change in a rather permanent way towards higher fitness. LbD is something demanding, causing fatigue; we met it in the best shipping companies: i.e. those we call "champions"... LbD is also important at ship's level, where senior staff has to teach the ones below. Moreover, learning by tradition (LbT) is the case when traditional wisdom is required in shipping ${ }^{11}$, and it has to be passed on, especially at ship's level.

\section{1) Planning Revenue}

In tramp shipping, revenue planning is not pursued, though one has ${ }^{12}$ to try. The inability to plan revenue is due to the fact that a shipping company does not

${ }^{10}$ Learning in management means to have any (relatively) permanent change in working behavior; it is expected when one is doing things better, as a result of gaining more experience, or from lessons learned, from the senior and experienced staff.

${ }^{11}$ One Captain by overlooking this truth caused a marine accident with 20 dead under conditions of bad weather. Tradition says that in case of high waves, the holes through which anchor chains pass, are made water proof.

${ }^{12}$ e.g. to create a data base with main particulars of all voyages accomplished by company's ships in last, say one year, and derive any repeated patterns of revenue. To use such results so that to derive certain laws, or... algorithms... Another way is to gather, and use, last year's EVR, adjusted for errors by "after chartering control section” (ACCS), for all company's vessels. 
know in advance what charter-parties company's ships will take-up during next year. This inability is derived from the definition, and from the reality, to be a tramp shipping company. Ships only in time charters have permanent gross revenue, but not a net one.

Planning of what company is going to spend is pursued, especially by applying the best available theoretical and empirical means and techniques concerning applied budgeting.

2) Planning Expenses

a) Who Has to Plan?

Company's economic manager, and mainly the chief accountant, has to organize and supervise the procedure to plan entire company's next year expenses. The expenses are all those required to run company's fleet, and will be planned per vessel, per expense code, per department, per month and for entire company, etc., and be saved in company's computer(s) (following company's accounting plan).

One should not copy blindly last year's expenses, if not repeated. He/she may even use last year's budget, adjusted mainly for international inflation, if no better method and data are available (e.g. "zero-base" budgeting). Good economic divisional and departmental managers have, however, to try, for an as far as possible, accurate budget.

\section{b) The Importance of Budget}

The budget of a vessel is the basis for...her chartering. I.e. the planned daily running cost of each vessel is compared with the offered daily freight rate in order to accept a business proposal. This procedure is known as estimated voyage result $(E V R)$. So, a lower budget has a chain reaction by accepting voyages that finally result to losses, and vice versa!

A corollary is that management of a shipping company is not like playing roulette/throwing dices, but it is a well-organized and planned business. A plan may be different than reality, but even this is pedagogical, and it triggers the intervention of ACCS and of economic manager. Planning, however, should not be erroneous, even if reality ${ }^{13}$ may come out to be different. What is wanted here is to eliminate error in EVR.

\section{c) The Procedure in Planning Vessel's Expenses}

Top-management, divisional managers and certain senior members of company's staff, and all departmental managers, have the authority, (which is better to be written down), to approve expenses. So, they have to plan them ${ }^{14}$.

\section{3) Control using Planning}

The deviations of expenses from those in budget, entitles economic division to manage, investigating the reasons of the deviations. Certain say that top-management has to deal with only important matters. But by signing payments, even of small ${ }^{13}$ Chartering dept. calculates EVR, and inserts dues to be paid e.g. for crossing Suez Canal. Assume that after a charter party signed, Suez Canal Authority increased overnight canal fees. This is an unexpected change.

${ }^{14}$ Computer provides every month actual expenses and planned ones; responsible staff has to find out the reason for a deviation. 
amounts, top-management...manages and controls ${ }^{15}$.

\section{Plans versus Reality}

Whatever is planned has to be compared with actual. Control without planning has no meaning, and vice versa. Moreover, planning may be related to positive financial results, according to theory. Personally, we see planning as a necessary, but not as a sufficient, condition...

In well-organized shipping companies there is a section dealing with the comparison of voyage actual results with EVR, as mentioned. This is important. We saw frequent and serious differences ${ }^{16}$ to emerge between EVR and actual. Due to such mistakes, a supposedly profitable voyage ended in losses, and this had to be avoided...if not punished, but surely they have to be investigated.

\section{Part II: The Revenue-Bringing Shipping Departments}

The difficult planning of vessel's revenue does not mean to abandon a continuous and persistent effort for it. Moreover, we must have management's focus for revenue increase! Top-management has to organize and boost the activities of revenue bringing departments/sections: i.e. freight collection, chartering, insurance claims and economic division.

\section{The Main Functions in a Shipping Company}

The goals that a shipping company sets are different for each department: Operations department, e.g., has to minimize the off-hire time of vessels; this means that all vessels must have a paid employment for... 365-6 days! This is an ideal maximum, no doubt. A more realistic target is at least 350 days.

Chartering e.g. has to choose the most profitable charters as shown by an accurate EVR. This, we believe, is one of company's top targets. This decision, however, involves top-management. In-house shipbrokers formulate their opinion, with points, as to why a particular voyage selected and proposed to management as more profitable (when 1-2 others rejected). They have to avoid obtaining top-management's approval to pass responsibility on. A competitive advantage, we saw, was obtained by shipping companies whose top-manager knew chartering well (e.g. Eastern Shipping Co Ltd.).

Technical department, e.g. has to minimize off-hire time of ships due to technical reasons ${ }^{17}$ (dry-docking; breakdowns; black outs; repairs after a marine accident), within department's budget. Supply department has to satisfy the reasonable needs of the vessel with best quality provisions, bunkers, paints, lubricants, chemicals, stores, water, laundry, spare parts etc., at lowest ${ }^{18}$ cost and quantity. Port Captains Dept. e.g. has to load/unload vessels properly, and fast, following the principles of a good and safe stowage. As a result, loading/unloading ${ }^{15}$ There are also traps when the payment of the same amount can re-appear a month after, due to bad organizing, and paid twice! Computers are there!

${ }^{16}$ Frequent mistakes are made in calculating ship's days in port and at sea. The one is due to using erroneous speed for vessel, weather excluded. The time spent in ports is important and may be miscalculated due to old information about port's facilities, congestion, strikes or weather (e.g. snow), working hours and days. Frequent mistakes are committed in Canal dues, port dues and agencies fees. Freight taxes are also wrongly calculated, if at all. Personal computers cab help.

${ }^{17} \mathrm{Planned}$ maintenance is a strategy for one to be ahead of technical problems.

${ }^{18}$ Efficient shipping companies maintain lists of ports that a particular item in provisions is cheaper; certain times due to season. 
means and hatch covers should be properly functioning; holds have to be clean.

Marine HRM (human resources management) department has to select the best Captains, officers and ratings, who respect vessel's safety and security and minimize her off-hire time, satisfy the reasonable needs of the charterers and minimize the cost of the vessel. These should manage the ship with due diligence, i.e. as if the ship was owned by them!

Insurance department has the ship insured for all sea risks and in a $\mathrm{P}+\mathrm{I}$ club, following the instructions of economic manager concerning cost of insurance ${ }^{19}$. This department also collects the money for company's claims, in time, from insurers, and cleverly determines the "deductible ${ }^{20 "}$ amounts for company's vessels (strategic matter).

Management eliminates trans-departmental antagonisms, which harm company. Management supervises by priority Chartering (Sales dept.) and Operations (Production dept.), due to their particular importance.

Table 1 summarizes the main information about the departments of a shipping company.

As shown, most of the shipping departments spend; others spend and collect, and three or four only collect. All departments, however, should save money and this is what top-management and economic manager have to implement! Spending departments should be strictly and closely controlled, first by their manager, secondly by economic manager and thirdly by top-management. The first best way is to approve their spending before actual spending, and the second best is spending to be in line with budget! The third, but not best, is to investigate spending after it has been done.

Large shipping companies have organized sections of cost control, and/or for watching company's rights on payments made by appointed persons on company's behalf, like e.g. Captains (e.g. Master's General Account, MGA) and Agents. Great economies can be achieved here. There are also companies that the cost control is not in their philosophy. Surely a shipping company has to compare the cost of... a cost control system (with) and the cost (without) it! In shipping companies are many those who want to benefit personally ${ }^{21}$, from inside and ${ }^{19}$ Our ship-model shows that $\$ 190,000$ p.a. had to be spent for insurance.

${ }^{20}$ Deductible is the $\$$ amount of a claim excluded from cover (self-insurance). The higher the deductible, the lower insurance cost. These claims are of a small value and of a high frequency, which insurance companies avoid for their high cost of administration. It is the same mentality when banks avoid giving many small loans instead of one big. Imagine the benefit to a bank of a loan of $\$ 100 \mathrm{~m}$ vis-à-vis 10 loans of $\$ 10 \mathrm{~m}$ each...

$\left.{ }^{21} 1\right)$ A meat supplier delivered to a vessel, in Rotterdam, half the amount of meat ordered by the company! The supplier, when checked by a company's person having the relevant invoices, "obliged" him to bring the missing amount. He argued that his delivery would be executed in two halves! 2) One person managed to receive part of chartering commissions in his personal account by charging company with a higher amount. 3) A partner and co-shipowner deposited all freights in his personal account; eventually company run out of cash! 4) A person in charge of disbursement accounts succeeded in buying... a Lamborghini car. 5) Many shipowners reported to have given loans or money (or bought shares getting back nothing) that they were never returned. 6) Foreign people believe that a $3 \%$ commission on orders is legal, but certain Greek shipowners do not. E.g. commissions are paid by shipyards to company's engineer supervising a new building; for order bunkers; for insuring ships and for supplies. 7) A Captain once replied to his company confirming receipt of paints: "I confirm the receipt of $\mathrm{x}$ amount of paints, which I have asked, and $\mathrm{y}$ amount sent by you"... 
Table 1. The spending and collecting money shipping departments.

Operations dept.: spending
\&collecting; it collects the
(accurate) amounts due to
company via the "Freight
Collection Section" (FCS);
the disbursement accounts
control section (DCS)
monitors \& reduces the
cost of company's
appointed Agents

\section{Marine HRM Dept. =} spending $\left({ }^{* * *}\right)$; in our ship-model, crew cost is $\$ 1,470,000$ p.a. for 26 persons under USA flag; $15 \%$ of total cost; the flag choice is a strategy, as well crew nationality

IT dept. = spending; it cares to adopt the latest and best available technology in communications, computers and networks

(***) Large companies have a performance engineer, who saves money from the proper function mainly of main engine; money is saved here

\section{Chartering Dept.: collecting;} bringing-in the freights \& hires in time; freights sometimes are lost or not paid (cases passed on to Legal dept.) $\left(^{*}\right)$; attention should be paid for who receives the commissions and what $\mathrm{a} / \mathrm{c}$ has to be credited with freights and hires; for ship-model, chartering had to accept a freight rate per ton greater than $\$ 10.36$ to cover total cost and have a profit of $\sim 12 \%$ p.a.

Port Captains Dept. $=$ spending

Economic Division $=$ spending $(* * * *)$, saving and collecting

$\left({ }^{* * *}\right)$ it cares to pay comparable wages among other companies
Supply Dept. = a par excellence spending dept.; it draws management's attention for cost control; a prudent and honest $\wedge \wedge$ manager $\left({ }^{* *}\right)$ must be appointed; important here is to specify who has to receive commission on company's supplies! \$95,000 for stores, supplies and equipment is spent for the ship-model

Insurance Dept. $=$ spending \&collecting via claims and P \& I clubs; it needs dexterity, experience \& knowledge to achieve the lower possible insurance premiums and collect the higher possible claims! It cares for cargo claims

${ }^{*}$ ) Legal dept. (collecting) pursues lost or unpayable freights and hires among other legal matters in various legal international regimes; claims have time bars which have to be observed

$(* * * *)$ It cares to achieve best loans, to protect company from foreign exchange risks; to secure high interest rates for company's deposits; it cares for company's liquidity and maintains good public relations with banks etc.; important dept.
Technical Dept.: is heavy spending $\left({ }^{(* *)}\right.$; to draw the attention by priority of top-management; to have control especially of the amounts of lubricants and bunkers consumed by main engine etc.; the control of spare parts etc. is absolutely necessary
Administration Division $=$ spending; caring for office staff recruitment ${ }^{\wedge} \&$ training, and for Secretariat dept. caring for office equipment etc. at best prices. $\wedge$ it cares to pay wages comparable with the rest of the industry
${ }^{* *}$ It cares so that expenses for crew provisions per head or per day to be equal or lower than other shipping companies; ship-model spends $\$ 50,000$ for crew subsistence p.a.
$\wedge \wedge$ honesty is the most sought after in connection with this the fuel cost of $\$ 1,980,000$ p.a. $\sim 20 \%$ of total cost of the ship-model; economize on this cost is important dept.; important is (at this time)

Source: Author ${ }^{22}$.

outside the company, and from inside and outside the vessel. Since human greed is without a limit, shipping companies have to control their cost, and more so their revenue, we believe.

Departments and sections bringing money obviously must be helped, by priority, to bring-in more money ${ }^{23}$. Departments that only spend must learn to save, especially during a depression. In large well organized companies there is a manual of how to save money, mainly by the vessel, during a depression, like the ones in 1981-1987 for dry cargo ships, in 1979-1992 for tankers and the latest from 2008 to 2016.

\section{Part III: What Vessel Has to Maximize?}

1) Maximizing Normal Profits (M1)

\footnotetext{
${ }^{22}$ Author used to be a departmental manager in two departments in a large Greek Tramp Shipping company from 1977 to 1990 . One department was that of Internal Control.

${ }^{23}$ This means to select staff carefully, train it, organize them properly, and provide them with all means (computers \& programs).
} 
This comes from Microeconomics. However, vessel's revenue is not known! Microeconomics further says: equalize MC (marginal cost) with MR (freight rate). But a shipping manager ignores how to calculate MC...Moreover, when we say M1 we must mean it for all vessels in a company's fleet!

For the above reasons, we wish to change the focus of microeconomics from maximizing normal profits (M1) to minimizing vessel's cost $(M 2)$, so that to adapt theory to practice. Moreover, M1 can be misleading for a shipping manager, a sit makes him to tolerate unprofitable vessels in the fleet. Imagine the entire company to perform well by having an overall positive annual profit say of $\$ 20 \mathrm{~m}$ (vessels' cross-subsidization). This though unwise, we saw it to happen in practice.

Surely, the vessel (new or second hand) proves her ability to earn profits after puther in the market. To be fair, we have to give a second chance to ships which brought once a loss, due to market conditions... But a vessel used to bringlosses has subsequently to be laid-up or sold or scrapped the soonest possible.

\section{2) Maximizing Vessel's Carried Tons (M3)}

Given that the freight rate is fixed, another proper objective for the manager should be: maximize the tons carried (M3), call it T,(or better expressed in ton miles to include distance); and this every time ship is chartered: i.e. $\mathrm{TR}=$ total revenue $=$ Tonnage, $\mathrm{T}$, hired/chartered times freight rate, $\mathrm{F}$, overvoyage 1 from $\mathrm{A}$ to B. So: Max.

$$
\mathrm{TR} 1=\mathrm{T} 1 * \mathrm{~F} 1
$$

where $\mathrm{F} 1$ is paid to individual vessel for her particular voyage. The rule M3 is simple: a vessel carries... tons of cargo for which she is paid; so the higher,(up to her dwt mark), the amount of tons she carries, the higher her receipts out of a voyage, given distance. This has a corollary: a ship carries more tons, the more voyages she does, in full, (up to 365-6 days and nights or $350 \mathrm{~min}$.) p.a.

Can a shipping manager maximize tonnage carried-out with vessel's given economic speed, and space, and with ship's given capacity and speed of unloading/loading means? There is a number of ways, few are mentioned below, but the obvious one is: cut down vessel's off-hire time (M4), i.e. time when vessel pays without being paid.

Another way is to increase vessel's speed by changing ship's main engine! And still another is to increase the capacity of her loading/unloading means by... replacing them. These interventions mean to change ship's isoquant! There are quite a number of methods to increase ship's production (= ship's performance) after construction, but this goes beyond our scope.

\section{3) Vessel's Equilibrium}

Figure 2 shows that the price (spot freight rate, OF) payable to a ship is determined by Supply and Demand. This holds for a specific cargo and voyage, from known ports, $\mathrm{A}$ and $\mathrm{B}$, with a fixed date of departure, at certain speed, etc., given also possible competitors in port $\mathrm{A}$ !

As shown, if vessel's average cost is BA (RHS), and MC2 = AC2, but greater 


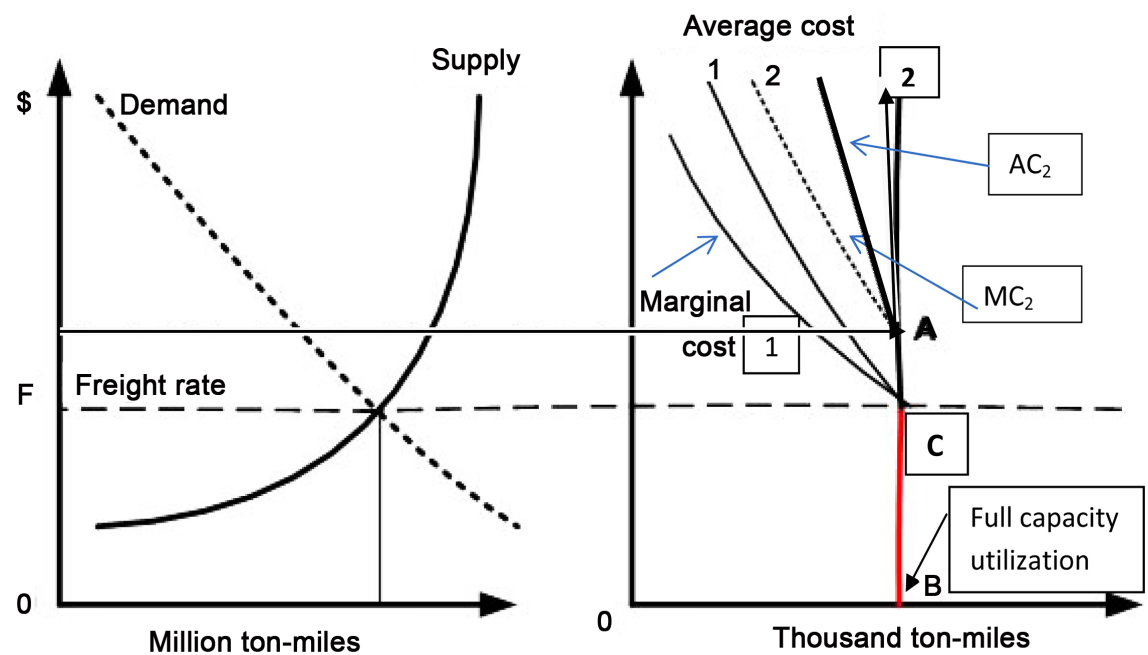

Figure 2. Vessel's price determination in short-run. Source: Author.

than $\mathrm{OF}$, vessel brings-in losses. At $\mathrm{OB}$, the vessel is fully loaded, and this is the reason for her cost curves, ( $\mathrm{MC}$ and $\mathrm{AC}$ ), to rise vertically beyond $\mathrm{B}$, where no more cargo can be received (100\% capacity utilization). If a vessel produces at a lower level than $O B$, the loss will be even greater, or the revenue lower, because the tonnage carried will be less than the maximum $d w t$ she can carry. There is a capacity \% where the total cost of the vessel will be greater than the total income from a charter, and this will lead to losses.

What then a vessel has to do to avoid next future loss, given that freight rate remains at $\mathrm{OF}$ ? The vessel has to reduce her cost from $\mathrm{BA}$ to $\mathrm{BC} . .$.

\section{Corollary}

A shipping manager cannot be evaluated on the grounds of not attaining a maximum normal profit! Shipping is a special case ${ }^{24}$, where the level of the net revenue achieved by other, similar, companies (M5), is the fair criterion. Similar companies are those with the same number, type, size of ships, as well other factors (e.g. depreciation for net profit), leaving-out only top-management! Shipping companies and vessels are in market to seek profits, no doubt.

\section{4) Vessel's Cost Minimization (M2)}

Cost minimization is the realistic economic objective for a vessel, which has to excel in competing other vessels performing same voyages. This is so especially if vessel's cost is above market price, as we saw.

\section{a) Vessel's Production}

Assume that a vessel produces uses only two factors: X1, standing for all inputs, except capital, including labor (crew), and X2, standing for Capital, embodied in vessel. The vessel is a special case in microeconomic production theory of the firm, because vessel's inputs quantities are fixed. In other words, vessel's isoquant is represented by a half square (Figure 3 ).

${ }^{24} \mathrm{We}$ saw in practice that companies with same vessels etc. earned less than others. So a shipping manager will be evaluated because his/her colleague, with the same capital (fleet etc.), earned $\$ 40 \mathrm{~m}$ in a year, while he/she earned only $\$ 20 \mathrm{~m}$ ! 


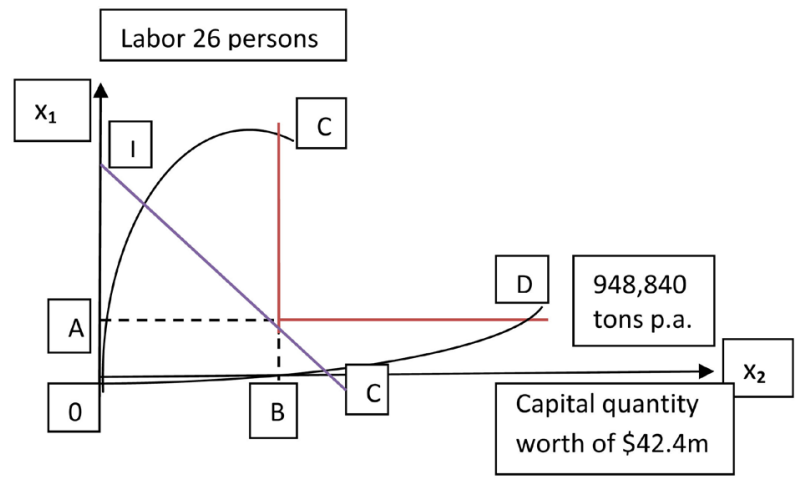

Figure 3. Vessel's isoquant, isocost and ridge lines. Source: Author.

As shown, vessel's ridge lines ${ }^{25}, 0 \mathrm{C}$ and $0 \mathrm{D}$, are drawn, but there was no need. Because, vessel's production is carried within the ridge lines due to positive quantities of capital and labor used (positive marginal products $1 \& 2$, MPs $>0$ ). This is the area of "rational operations" where vessel produces with technical efficiency. The owner of the ordered vessel has the technical information from the shipyard that the combination, e.g. in a newly-built vessel (tanker) of 30,000 dwt with 26 persons crew, will produce a maximum (net) cargo of 27,344 tons per voyage ${ }^{26}$. This is a technically efficient production function of the vessel:

$$
q^{0}=f\left(x_{1}^{0}, x_{2}^{0}\right)=948840(\text { tons per year })
$$

where $x_{1}=26$ persons, $x_{2}=30.000 \mathrm{dwt}$. The owner, we believe, has selected: vessel's desired size and speed, and her loading/unloading means (cranes, pumps).

Moreover, the owner chooses the desired size taking into account ship's economies of scale (Figure 4).

As shown, there are three vessel's sizes producing 30,000t $<70,000<160,000$ dwt of cargo per voyage. First, we assume that the larger sizes of the ship shown are feasible to be built ${ }^{27}$ ! Notable is the lower quantity of labor used $(0 \mathrm{a}>0 \mathrm{~b}>$ $0 c)$ as size increases, and the greater quantity of capital embodied $(0 \mathrm{~d}<$ oe $<$ of $)$ as ship size increases. The quantity of capital is increased, but in a slower pace than production. This means economies of scale in production.

Economies of scale, in economics, however, means lower cost per ton carried (average cost), given full capacity utilization.

\section{b) The Meaning of Vessel's Production Function}

Vessel's production function determines the maximum output per voyage (e.g. 27,344 tons ${ }^{28}$ given ship's speed and voyage distance), derived from a ${ }^{25}$ Ridge lines are not defined.

${ }^{26} \mathrm{We}$ will make frequent reference to a real case using the particulars of a tanker newly built of 30,000 dwt trading in USA ports in 1980s from [8] (p. 369).

${ }^{27}$ Onassis challenged shipbuilders by building ships much bigger than hitherto. The maximum maximorum size of a ship is a strategic matter, depending also on sea depths in ports, widths of Canals, size of shipments (load units), availability of cargo etc. Strategic are also: the size of the main engine; her speed; kind of fuel (oil? gas? methanol? other?); kind of cargo etc.

${ }^{28}$ Note that the $30,000 \mathrm{dwt}$ provide only 27,344 tons of cargo; 2656 tons are carried with no charge! This costs $\$ 27,500$ per voyage and there must be a strategy to reduce it to a minimum, (i.e. these are the weights of water; bunkers; crew; added equipment, etc.). 


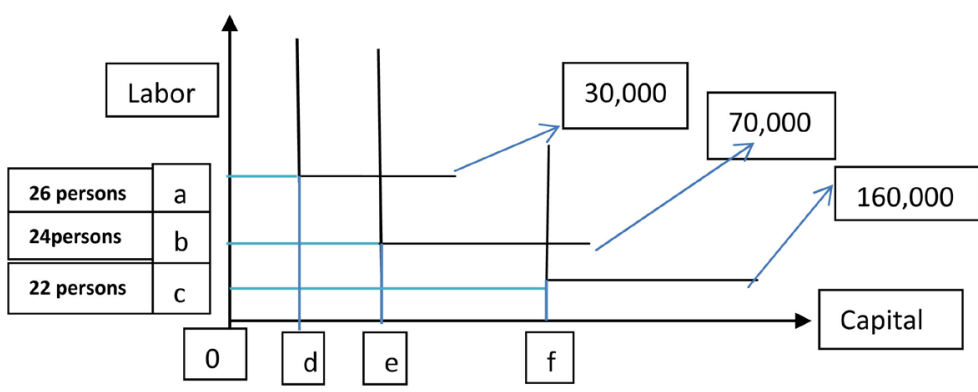

Figure 4. Economies of scale in vessel's production.

particular combination ${ }^{29}$ of $X_{1}$ with $X_{2}$, as mentioned. This combination, out of $\infty$, is selected by ship owner. Economics, however, to complete production,

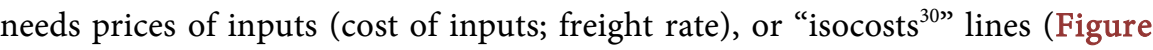
3), so that to introduce economics into technology [18].

\section{c) Vessel's Cost Minimization in Rigorous Terms}

To minimize vessel's total cost:

$$
C=r_{1} x_{1}+r_{2} x_{2}+b^{31}
$$

where $r_{1}$ is the price of capital ${ }^{32}, r_{2}$ is the price of labor ${ }^{33}$ and $b$ fixed cost, we have to subject it to production function (2). All prices are constant in perfect markets. So, we form: Min.

$$
Z=r_{1} x_{1}+r_{2} x_{2}+b+\lambda\left[f\left(x_{1}, x_{2}\right)\right]
$$

and equalize the three partial derivatives of $Z$ with respect to $X_{1}, x_{2}$ and $\lambda$, to zero to obtain a minimum. The result is that RTS (the ratio of technical substitution) has to be equal to the ratio of prices of capital and labor:

$$
\mathrm{RTS}=r_{1} / r_{2}
$$

Equation (5) means that Figure 3 needs an "isocost" line -IC, to be complete. So, the optimum combination of capital and labor is given at the point of tangency of isocost line, IC, with isoquant, $q^{0}$.

\section{4) The Efficient Shipping Manager}

The efficient shipping manager tries, always, to do three actions, before market conditions (Figure 5): 1) to control vessel's and company's cost; 2) to decide fast within best-timing, and 3) to choose the most profitable from available charters.

Doing the above, the top-manager is the king among his/her colleagues, but

${ }^{29}$ The $\$$ capital embodied is determined by ship's size mainly; the size of crew is then determined by flag. It counts what automations the ship has, but the trend is for less crew. This is so as crew in advanced shipbuilding countries is expensive. Ships have a laundry on board as well hot water.

${ }^{30} \mathrm{An}$ isocost line is the locus of input combinations that may be purchased with a specific total cost.

${ }^{31}$ There are certain inputs, which do not change with changes in output $(=b)$.

${ }^{32}$ Capital cost comes from vessel's price amortized over say 20 years (=ship's life) or 7200 days (a $360\left(^{*}\right)$ days year assumed) aiming at a yield of $\sim 12 \%$. For the vessel-model having a price of $\$ 42.4 \mathrm{~m}$, her capital cost is $\$ 4,980,000$ p.a. and given that the vessel performs 34.7 voyages per year, then her capital cost is $\$ 143,516$ per voyage. $\left({ }^{*}\right)$ A more realistic year is that of 350 days; also the vessel must have a residual (scrap) value not mentioned.

${ }^{33}$ Labor stands also for all other inputs, like e.g. bunkers etc. 


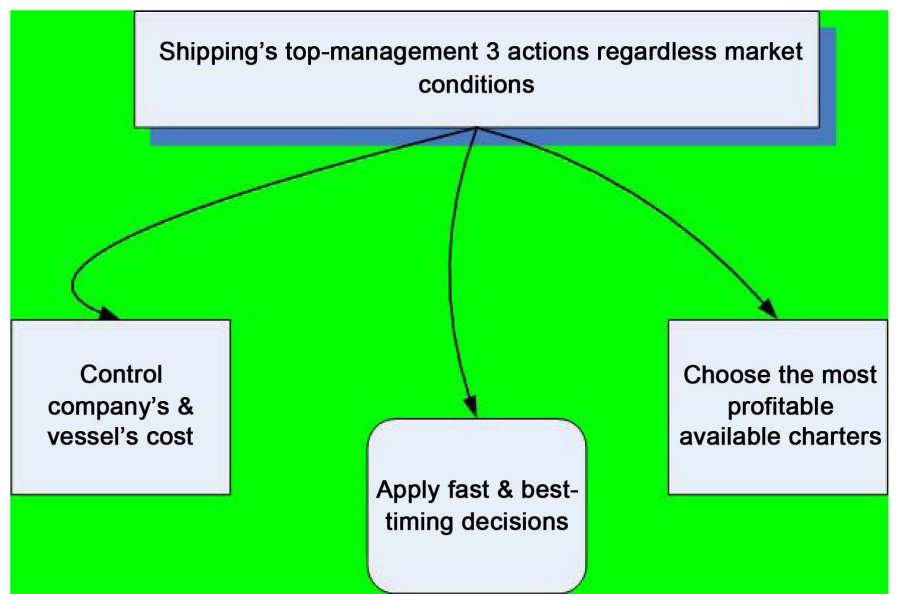

Figure 5. Actions required by top-management for a shipping company and a vessel to excel. Source: Author.

he/she cannot secure ${ }^{34}$ a higher spot freight rate for company's vessel! So, it is better for top-management to achieve one or all of the seven objectives, which we set, excluding profit maximization: M2: minimizing vessel's cost; M3: maximizing vessel's tons carried; M4: minimizing vessel's off-hire time; M5: excel vis-à-vis competitors; M6: plan for next depression and M7: create depression reserves.

\section{Part IV: Plan and Then Plan Again}

\section{1) Available Plans}

Nine different plans are provided by theory [1]: strategic, operational, long term, short term, specific, directional, single use, intermediate and standing. We added also a $10^{\text {th }}$ plan for maritime depression, because shipping companies face a crisis every 12 years on average [19]. The many plans, for us, simply indicate the need of companies for an efficient and effective planning. The above plans indicate the agony of management to be of real assistance to modern managers! We believe that there is an illusion that with a plan, and with no accurate forecasting, a shipping manager can excel. But it is sure that without a plan, market will trouble this manager... Thus we believe a shipping plan to be necessary, but not a sufficient condition for a successful management...

\section{2) Plan for a Depression}

Given that our theory about a shipping manager, and his/her Captain(s), is to minimize vessel's cost, we expect it to be adjustable, percentage-wise, in line with market conditions ${ }^{35}$. This plan has to be prepared and be the alternative in ship's computerized year (boom) plan. If market falls, and especially below ship's cost,

\footnotetext{
${ }^{34}$ This can be done by avoiding the market; i.e. by negotiating with cargo owners directly.

${ }^{35}$ If freight rate falls, say by $20 \%$, meaning for the ship-model a lesser annual income of $\sim \$ 1.97 \mathrm{~m}$ $(\$ 9.83 \mathrm{~m} * 20 \%)$ and given that capital cost, fuel and insurance of $\$ 7.15$ cannot be reduced, then the remaining cost of $\$ 2.68 \mathrm{~m}$ have to be reduced to $\$ 0.71$. So, we change flag, and reduce: crew salaries by $\mathbf{6 0 \%}$ (to $\$ 0.588 \mathrm{~m}$ ); subsistence of crew by $\mathbf{2 0 \%}$ (to $\$ 0.04 \mathrm{~m}$ ); stores etc. by $\mathbf{5 0 \%}$ (to $\$ 0.0475 \mathrm{~m}$ ); maintenance and repairs by $\mathbf{9 9 \%}(\$ 0.0345 \mathrm{~m}$ ) (given that vessel is new). As shown the reduction in freight rate by $20 \%$ requires a greater $\%$ reduction in certain cost items mainly crew. If the above cost reduction is not possible then capital cost (yield) has to be reduced by $\sim 40 \%$.
} 
then ship's depression plan to be applied for now on; expenses to be determined by this plan. Shipping companies know how to reduce costs. This plan is advisable to be planned in consultation with company's Captains.

\section{3) Planning}

Planning requires to set goals, and to establish strategies for achieving the goals set; to develop plans so that to integrate and coordinate work activities. Managers must specify what, and how to plan, i.e. to specify the ends and means of planning.

Planning is easier when changes are mild or revenue is stable or increasing. However, in shipping, par excellence, demand may change abruptly, unlike supply, due to a sudden depression -like the ones in 1981-1987 and in 2009-2016 for dry cargoes, and in 1974-1987 for tankers, and the one in 1929-1933 [16].

No shipping manager could ever forecast a shipping depression, making industry, as a result, unpredictable. This is the reason we recommend shipping managers to create depression reserves (M7) from boom profits (e.g. 2003-2008) to face depression (e.g. 2009-2016). Many shipping managers say: "We know that a shipping crisis will eventually come, but we do not know when and how long it is going to last"...Our suggestion is: "plan for next depression" (M6) and (M7)!

\section{4) Questions Related to Planning}

a) Why to plan? Planning provides direction to all, including top-management. It is important for the departments to know what their goals are. Also, more important is to know how each department will contribute to company's goals, how this to be coordinated and whether this needs co-operation from other departments. Planning has to indicate how company's goals are accomplished.

Planning is preferred to no-planning, because it helps control. Planning reduces uncertainty. Planning concerns future and thus makes managers to look forward. It anticipates possible planned changes; it considers beforehand the impact of a change and applies planned proper responses. Planning may reveal inefficiencies or inconsistencies in departmental plans.

Management via planning of expenses controls the daily running cost of each and all vessels, and compares this with that of last year and how much less competitive company became, and what to do about it. Planning is needed for control, especially if it establishes goals and standards. In shipping, expenses are planned at their reasonable levels, and should not be exceeded during planned year. If this happens, economic manager has to investigate how and why. This is surely a way of managing a company. With no expenditure planning, control has no basis.

b) Does planning improve performance? Planning is related to positive financial results, according to theory, i.e. higher profits, higher returns etc. Further, trying to implement planning, one may improve the targets or learning by implementing the plan (LbIP).

Imagine now a Government to approve a 30\% rise in seamen's wages retrospectively. This will destroy the plan of the MHRM department. Imagine a sud- 
den decision from OPEC to raise oil price from $\$ 50$ a barrel to $\$ 75$. Imagine a rise in international repair cost of $30 \%$. Imagine also an unexpected rise of insurance premiums by $20 \%$, let alone the possible and inevitable payment of back calls by $\mathrm{P}+\mathrm{I}$ clubs. So, there are many unexpected factors that may destroy a plan! So, plans must have flexible and adjustable to reflect reality.

Notable is the fact that budget is done during working hours and one may not pay the proper attention to it, because it prevents him from his current, sometimes urgent, targets. But planning is equally important.

c) Types of shipping plans: In a shipping company standing plans are most common, meaning ongoing plans providing guidance for activities performed repeatedly (e.g. via company's circulars). Less common are the long term plans, which need a time of over 3 years. Worth noting is that in the more stable past, companies could plan for 7 years! Common are also the short term plans for one year, as is budget.

Intermediate plans are those between 1 and 3 years. For the revenue of a shipping company we may use the directional plans, which are flexible, and set general guidelines. For the vessel, the specific plans are better as being clear, and leave no room for personal interpretations. For the vessel also a single-use plan may be used, which is one time plan specifically designed to meet the needs of a unique situation (e.g. a major repair; a dry-docking).

Finally, the strategic plans apply to entire company and establish company's overall goals in a long future. These come from top-management. Top-management decides a company's strategy especially in building ships or buying/selling ones. Moreover, operational plans encompass a particular operational area of the company, like e.g. Operations or Chartering Departments.

Suppose now that an operator has to reduce vessel's yearly off-hire time by $10 \%$, i.e. about 35 days. This requires a more careful voyage plan as hitherto by paying attention to times spent by the ship, for which she is not paid: when ship arrives at anchorage; the speed applied; broadcasting properly the notice of readiness; shifting from berth to berth; breakdowns in loading, or unloading; delays; bad planning for the repatriation of crew, or receiving replacements on board; await for class/PSC inspectors to come from a far away and expensive port; await receiving missing charts; awaiting for tugs, and their number etc.

Captains must realize that revenue earned by the vessel is divided by ship's year working time, expressed in days. There are surely justified certain off-hire times, in theory this is 15 days per year, when also insurance premiums have to be reduced(if e.g. vessel is in repairs), but as we have mentioned already, cost in shipping runs, even when vessel does not earn, or when ship is laid up. Only the sale or scrapping of the ship terminates the expenses!

Operators, we think, do not pay attention, to the importance of ship's time lost in vain. Operators must realize that a ship can earn additional $\$ 27,218$ per day, if not in off-hire, (using our ship-model), and for 15 days this equals $\$ 408,270$ p.a.! 


\section{Part V: Management by objectives}

$\mathrm{MbO}$ is suitable for a large shipping company (20-30 vessels or more), we believe. $\mathrm{MbO}$ is a process of setting mutually agreed-upon goals, which are then used to...evaluate staff's performance. It is true that $\mathrm{MbO}$ adopted by many large international companies [1].

Shipping companies, according to our experience, apply $\mathrm{MbO}$ in a modified way by giving bonuses, when individual projects are carried-out successfully. This bonus, however, is recommended by departmental managers ex post and is not in the system as permanent.

The secret of $\mathrm{MbO}$ we reckon is to plan for each and every one; i.e. every one to have and know well its personal plan, and know how to implement it successfully. Table 2 shows the steps in an MbO program.

As shown, $\mathrm{MbO}$ mobilizes all levels of authority in a company: top-management, divisions ${ }^{36}$, departments and staff. Each one has his/her plan and it is explained, and agreed also, how to achieve the specified objectives. Control is necessarily applied, and good action is rewarded. The procedure is similar in general terms to that followed by large shipping companies for expenses, except for $8^{\text {th }}$ step. This procedure uses elements from motivation theory ${ }^{37}$. To incorporate budget into $\mathrm{MbO}$ is easy; to incorporate M1-M7 objectives faces more difficulties.

For budget, we need the names of the responsible persons for expenses and then we may reward them with a letter of recognition-if not with a bonus-if they retained expenses within budget's limits or even below. Research has shown that $\mathrm{MbO}$ can increase staff's performance and company's productivity [1] [20].

Table 2. Can MbO be applied to large shipping companies?

Formulate company's
overall objectives $\&$
strategies by
top-management
$\left(1^{\text {st }}\right.$ step)

Write down specific action plans to define how objectives are to be achieved \& agreed upon them by dept. managers with employees ( $5^{\text {th }}$ step)

Departmental managers
to set specific objectives
for their departments in
collaboration with the
divisional managers
$\left(3^{\text {rd }}\right.$ step $)$

Departmental managers to set specific objectives in collaboration with all departmental staff ( $4^{\text {th }}$ step)

Successful achievement of the objectives is reinforced by performance based rewards ( $8^{\text {th }}$ step)

Source: Author inspired by [1].

${ }^{36}$ Divisions in a shipping company, if at all, are few: 1) Administration with Office personnel dept., public relations dept. as well Secretariat; 2) Economic with Accounts, Internal auditor-if any, and IT. ${ }^{37} \mathrm{~A}$ theory determining the process by which a person's efforts are energized, directed and sustained towards attaining a goal. 


\section{Part VI: Management by Looking At}

Let us visit the future "operations room" of a large tramp shipping company. We have organized it so that data from ships to come in 24 hours a day. This is company's Global Operations and Control Center (GOCC), where numerous computer screens relaying video and data keep watch on company's ship operations round the world ports ${ }^{38}$.

Operations manager, operators and port captains and others can get information on ship's loading/unloading using ship's cameras; by installing a number of cameras we enjoy a close monitoring of ship's activities. In other words, we have replaced management by distance $(\mathrm{MbD})$ with management by looking at $(M b L A)$ ! Cameras are installed in all places of interest ina vessel (engine room; bridge; decks; holds etc.).

\section{The Practical Significance of Research}

Almost all academics and researchers, outside shipping companies, ignore management of a shipping company and of a vessel. This paper-from inside shipping-helps people to understand shipping industry and especially tramp shipping. This is addressed to prospective shipowners and to those small ones to see what have to expect when they grow. Also we stressed that cost (and budget) is the king in shipping along with timing, and we showed that there is a hope through "distance surveillance ${ }^{39}$ innovations" to manage by looking at vessel's operations, and not only. This last novel innovation-which we will further elaborate in future papers-will change structurally the management of a ship as we know it. The whole ship management is based on an obligatory alter ego (Captain), who is continuously and closely controlled from a distance, involving a cost and creating cases of disobeying office's instructions at a great cost!

\section{Concluding Remarks}

Notable is that there are two management styles in shipping: 1) when company's manager is a different person than owner, and 2) company's manager and owner are the same person (Greek style). Managing a shipping company nowadays is management by distance ${ }^{40}$. The vessel is really managed, more effectively, by her Captain due to his/her closeness.

Moreover, to have a budget, a high degree of formalization ${ }^{41}$ and a continuous control, are the necessary tools to manage by, and due to, distance. In addition, the effectiveness of communications, as well of their cost, etc., is now important. The novel idea of this paper is to introduce management by looking at the ves-

\footnotetext{
${ }^{38}$ Most shipping companies kept a world map and put pin-flags to show where company's ships are. ${ }^{39}$ Applied already by other large companies to look at the operations of their factories from a distance!

${ }^{40}$ Certain large Greek shipowners (Eastern Sh. Co Ltd.) have applied also "management by walking around", which describes the case when a shipping manager is out in the work area interacting directly with his/her employees.

${ }^{41}$ How much standardized vessel's jobs are and the extent to which crew behavior is guided by clear rules and procedures (office circulars).
} 
sels.

To take decisions, as fast as, or faster, than the market, is necessary; but more necessary is best-timing. The fast decision-making is not automatic! It must be organized! Thus a simple organizing with few- and computerized-hierarchical levels, where top-management decisions travel fast down, and executed immediately, and where one single top-manager decides (Greek shipping style) are essential.

We showed planning in a large tramp shipping company and the benefits of planning during a depression. We mentioned the goals in a shipping planning, and warned top-management not to be misled by economists requiring "normal profits maximization", when market denies it! We established in shipping management the motto of ancient Greeks: "Be better than all the others (excel)"; this is what Achilles' father Peleus said to his son Achilles, when he departed for Troy War, though he was considered to be a semi-God!

A shipping company's prime goal is not only to keep off-hire times at a minimum, but also this to be a goal of every shipping department, as the case may be. The departments that bring-in money need every support to bring-in more money, by priority, and the departments that spend money to control their cost or increase their saving.

We showed that from the nine plans provided, we distinguished one from the other, and indicated the usefulness of each. Management has to know what and how much a shipping company can derive a benefit from planning, and the reasons why, and again to know that a good planning, however good, cannot beat the market. He/she has to beat his/her competitors.

A good plan may reduce company's psychological uncertainty, it may save time to act, but it cannot bring-in money... I expect managers to understand the old panacea called management by objectives $(\mathrm{MbO})$, or optimal $\mathrm{MbO}$, and formulate an attitude towards it, as one may be called to apply it... as a manager of a shipping company.

\section{Conflicts of Interest}

The author declares no conflicts of interest regarding the publication of this paper.

\section{References}

[1] Robbins, S.P. and Coulter, M. (2012-2016) Management 13E, Pearson, USA.

[2] Goulielmos, A.M. (2002) Complexity Theory Applied to Management of Shipping Companies. Maritime Management \& Policy, 29, 375-391. https://doi.org/10.1080/03088830210144305

[3] Downard, J.M. (1981) Running Costs. Fairplay Publications, London.

[4] Downard, J.M. (1984) Managing Ships. Fairplay Publications, London.

[5] Robbins, S.P. (1990) Organization Theory: Structure, Designs and Applications. 3rd Edition, Prentice Hall, Upper Saddle River.

[6] Erskine, R. (1991) Business Management. Prentice Hall, Upper Saddle River. 
[7] Romani, P.N. (1997) “MBO” by Any Other Name Is Still MBO. Supervision, 6-8.

[8] Buckley, J.J. (2008) The Business of Shipping. 8th Edition, Cornell Maritime Press, Centreville.

[9] McConville, J. (1999) Economics of Maritime Transport: Theory and Practice. The Institute of Chartered Shipbrokers, London.

[10] Lorange, P. (2009) Shipping Strategy: Innovating for Success. Cambridge University Press, Cambridge.

[11] Jusko, J. (2010) Unwavering Focus. Industry Week, 26.

[12] Drucker, P. (2007) The Practice of Management. Butterworth-Heinemann, Cambridge.

[13] Sharon, G. (2016) The OPTIMAL MBO: A Model for Effective Management-byObjectives Implementation. European Accounting and Management Review, 2, 42-55. https://doi.org/10.26595/eamr.2014.2.2.3

[14] Duffy, M.F. (1989) ZBB, MBO, PPB and Their Effectiveness within the Planning/ Marketing Process. Strategic Management, 10, 163-173. https://doi.org/10.1002/smj.4250100206

[15] Guiso, L., Sapienza, P. and Zingales, L. (2015) The Value of Corporate Culture. Financial Economics, 117, 60-76. https://doi.org/10.1016/j.jfineco.2014.05.010

[16] Goulielmos, A.M. (2019) Forecasting the Next Dry Cargo Shipping Depression beyond 2018, Modern Economy.

[17] Goulielmos, A.M. (2017) The Great Achievement of Greek-Owned Shipping (19462017) and Keynes' Animal Spirits. Modern Economy, 8, 1186-1210. https://doi.org/10.4236/me.2017.810082

[18] Henderson, J.M. and Quandt, R.E. (1958) Microeconomic Theory: A Mathematical Approach. McGraw-Hill Book Company, Inc., New York.

[19] Stopford, M. (2009) Maritime Economics. 3rd Edition, Routledge, Abingdon-onThames.

[20] Rodgers, R. and Hunter, J.E. (1991) The Impact of Management by Objectives on Organizational Productivity. Journal of Applied Psychology, 76, 322-336. https://doi.org/10.1037//0021-9010.76.2.322 